NBER WORKING PAPER SERIES

\title{
THE CHOICE BETWEEN INCOME AND CONSUMPTION TAXES: A PRIMER
}

\author{
Alan J. Auerbach \\ Working Paper 12307 \\ http://www.nber.org/papers/w12307 \\ NATIONAL BUREAU OF ECONOMIC RESEARCH \\ 1050 Massachusetts Avenue \\ Cambridge, MA 02138 \\ June 2006
}

This paper was presented at a conference on Key Issues in Public Finance, held at NYU, May 2006. I am grateful to Dan Shaviro, my discussants Glenn Hubbard and Al Warren, and other conference participants for comments on earlier drafts. The views expressed herein are those of the author(s) and do not necessarily reflect the views of the National Bureau of Economic Research.

(C)2006 by Alan J. Auerbach. All rights reserved. Short sections of text, not to exceed two paragraphs, may be quoted without explicit permission provided that full credit, including $\odot$ notice, is given to the source. 
The Choice Between Income and Consumption Taxes: A Primer

Alan J. Auerbach

NBER Working Paper No. 12307

June 2006

JEL No. H20

\begin{abstract}
It has now been nearly three decades since the publication of two important volumes that laid out many of the details of how one might implement a progressive consumption tax (Institute for Fiscal Studies, 1978; U.S. Treasury, 1977). Over the years since, many contributions have analyzed the mechanics of the different variants of consumption taxation, the potential efficiency and distributional effects of their adoption, the issues of administration and transition from the current tax system, and the problems relating to certain types of transactions. But much of what we "know" is not part of the general policy discussion and there are important issues that the literature has recognized but still not resolved. The aim of this paper is to lay out the key economic issues involved in deciding whether and how to adopt a consumption tax and to discuss what theory and evidence have told us and could tell us about these issues.
\end{abstract}

\author{
Alan J. Auerbach \\ University of California \\ 549 Evans Halls \\ Berkeley, CA 94720-3880 \\ and NBER \\ auerbach@econ.berkeley.edu
}




\section{Introduction}

It has now been nearly three decades since the publication of two important volumes that laid out many of the details of how one might implement a progressive consumption tax. The Structure and Reform of Direct Taxation (Institute for Fiscal Studies, 1978; hereafter referred to as the Meade Committee Report) was produced in the United Kingdom by a group of economists and other academics. Blueprints for Basic Tax Reform (U.S. Treasury, 1977, reprinted as Bradford et al. 1984; hereafter Blueprints) came from the staff of the U.S. Treasury, working under David Bradford, who was Deputy Assistant Secretary for Tax Analysis while the report was being prepared. Both reports focused on the direct individual consumption tax envisaged by such earlier authors as Fisher (1939), Kaldor (1955) and Andrews (1974), rather than on the indirect consumption taxes already in place, notably value added taxes. Since the publication of these two volumes, though, there have been new ideas about how to combine the simplicity of indirect taxation and the progressivity and flexibility of direct taxation, notably the Flat Tax (Hall and Rabushka 1985) and the X Tax (Bradford 1986).

Over the years, there have been many, many contributions analyzing the mechanics of the different variants of consumption taxation, the potential efficiency and distributional effects of their adoption, the issues of administration and transition from the current tax system, and the problems relating to certain types of transactions. We now have a better idea of how to implement a consumption tax, and of what adopting a consumption tax would mean for the economy. But much of what we "know," from the recent literature and indeed from the Meade Committee and Blueprints, is not part of the general policy discussion, and there are important issues that the literature has recognized but still not resolved. The aim of this paper is not to survey the vast literature on consumption taxes, but to lay out some of the key economic issues 
involved in deciding whether and how to adopt a consumption tax, and to discuss what theory and evidence have told us and could tell us about these issues.

\section{What is a Consumption Tax?}

It may seem tautological that a consumption tax is a tax on consumption, but no tax currently in effect or realistically proposed is a consumption tax by that simple definition. To see this, we start with the product and income sides of the national income identity for Gross National Product $(G N P)^{1}$,

$$
G N P=C+I+G+X-M+R^{f}=W+R+R^{f}
$$

where $C$ is consumption, $I$ is gross domestic investment, $G$ is government spending, $X$ is exports, $M$ is imports, $W$ is wage income, $R$ is domestic gross capital income, and $R^{f}$ is net foreign income, i.e., foreign income of domestic residents less domestic income of foreign residents. ${ }^{2}$ The standard method for imposing consumption taxes, as under the VAT, is to start on the income side, taxing all factor returns but then forgiving taxes on sales that do not represent consumption, in particular:

$$
C=W+R-I-G-X+M
$$

so that sales for investment and export are free of tax while tax is imposed on imports.

In principle, government purchases should also be excluded from the tax base, although this will not matter if the government budget adjusts to the treatment of government purchases. That is, if government purchases are added to the tax base, and the government budget is then

\footnotetext{
${ }^{1}$ The right-hand side of expression (1) is referred to as Gross National Income, differing from GNP only by the statistical discrepancy that arises in measuring the same aggregate on the product and income sides.

${ }^{2}$ The notation used for net foreign income reflects that fact that most such income is capital income.
} 
expanded to cover the additional cost of government purchases, there will be no real impact there need be no change in the quantities of goods and services the government purchases. Of course, if the government budget does not adjust, or if the federal government taxes the purchases of state and local governments and makes no compensating transfers to these lowerlevel governments, then taxing government purchases will reduce real government budgets. While this issue may be quite important in evaluating specific tax proposals, it is straightforward conceptually. For the remainder of the discussion, then, I will ignore this issue, assume that the consumption tax has no impact on government purchases, and simply leave government spending out when using the national income identity, starting instead from expression (2'):

$$
C=W+R-I-X+M
$$

It is useful to introduce another identity, the international accounts identity which requires that the current and capital accounts must balance ${ }^{3}$ :

$$
\left(X-M+R^{f}\right)+\left(-I^{f}\right)=0
$$

where $I^{f}$ is net foreign investment. Combining (2') and (3) yields:

$$
C=W+(R-I)+\left(R^{f}-I^{f}\right)
$$

which emphasizes that a consumption tax can also be conceived as a tax on wages plus taxes on the net cash flows (gross income less gross investment) from domestic and foreign activities.

The simplest manner in which "consumption" taxes do not tax consumption is by omitting certain elements of consumption from the tax base. It is common for VATs to "zero

\footnotetext{
${ }^{3}$ For simplicity, expression (3) omits international transfer payments from the current account balance. Such transfer payments include government and private foreign aid as well as tax payments to foreign governments.
} 
rate" certain commodities, for example, with the objective of achieving more progressive taxation, notwithstanding the weak theoretical arguments for relying on variations in indirect tax rates for this purpose in the context of a broader system that includes progressive direct taxes. But the more complex deviations from consumption taxation occur through the exclusion of certain elements of the cash flows $(R-I)+\left(R^{f}-I^{f}\right)$.

\section{A. Consumption Taxes and Wage Taxes}

For a zero-present-value investment made today, the future additions to $R$ or $R^{f}$ are equal in present value to the cost of today's investment added to $I$ or $I^{f}$. Thus, with tax rates constant over time, the decision of whether to include or exclude these cash flows would have no impact on the present value of government revenues, nor would it have any impact on the incentive to undertake these marginal investments - the effective tax rate on such investments would be zero under both approaches.

Both Blueprints and the Meade Committee recognized this equivalence and envisioned giving taxpayers a choice under a personal expenditure tax of whether assets held at arms length would be subject to cash flow taxation or simply tax exempt, with both investments and returns ignored by the tax system. ${ }^{4}$ Indeed, both volumes saw an advantage in giving taxpayers a choice when tax rates $d o$ vary over time and hence the present value of cash flow taxation is not zero for marginal investments. Under a progressive expenditure tax for which marginal tax rates could vary over time, the ability of taxpayers to choose between the two forms of tax treatment would provide an averaging device, allowing taxpayers to shift their tax bases from high-rate to lowrate years while holding the present value of the tax base constant.

\footnotetext{
${ }^{4}$ Blueprints referred to assets included under the cash flow tax as "qualified" assets, while the Meade Committee distinguished between registered assets (those subject to the cash flow tax) and unregistered assets.
} 
As the subsequent literature has clarified and elucidated (e.g., Gordon 1985, Kaplow 1994, Warren 1996, Weisbach 2004), the same equivalence holds for risky assets, assuming that taxation of gains and losses is symmetric and that investors can scale up holdings to offset the government's implicit equity position. The investor would simply increase holdings of risky assets in order to undo the reduction in risk and out-of-pocket cost that the cash flow tax would produce, with the result that after-tax cash flows would be identical under the two alternative approaches to taxation. This equivalence at the investor level, though, leaves open what happens to risk taking in the economy as a whole. The answer depends on whether capital markets efficiently pool risks, a question to which I return below. If asset markets are efficient, though, the increased riskiness of the government's share of risky assets under the cash flow tax could not be reduced by pooling; once the government transmitted this risk back to the economy, the added "background" risk would offset the propensity for increased individual purchases of risky assets, leaving the equilibrium unaffected by the decision of whether to include the cash flows from risky assets in the tax base.

Another conclusion of this literature, to which I also return below, is that the income tax differs from the consumption tax only in its taxation of the safe rate of return on assets. To the extent that an asset's return is simply an excess return that compensates for risk-taking, the investor can undo the income tax by scaling up the position in the risky asset. Only the tax on the safe rate of return cannot be undone by this portfolio shift, and thus only the tax on the safe rate of return is relevant in assessing the distortion of an individual's intertemporal decisions.

Thus, whether investments are safe or risky, excluding from a consumption tax the cash flows on new, marginal investments would, to a first approximation, have no impact on the economy. But there are remaining components of the cash flows $(R-I)+\left(R^{f}-I^{f}\right)$ which 
may be grouped into two categories: the normal returns (including recovery of principal) from earlier investments and supernormal economic rents. It is useful to distinguish these two sources because opinions vary as to how these elements of the cash flow tax base should be treated in a transition from the income tax to the consumption tax. In particular, some view the tax on returns to existing capital as an unfair byproduct of the transition from one tax base to another, as only the net returns, rather than the recovery of capital, would be taxed under the income tax. Imposing a consumption tax therefore introduces a levy on the sale of existing assets. The taxation of economic rent, on the other hand, is typically not viewed with such concern, because rent would be taxed equally under an income tax or a consumption tax. There may also be different incentive effects if these taxes are anticipated prior to their enactment, because an anticipated levy on the recovery of capital is effectively capital income tax.

For some assets, notably owner-occupied housing and other consumer durables, it would be difficult to impose a cash-flow tax because this would require the taxation of imputed rental income. That is, we observe the investment flows as components of $I$ but we do not observe all the components of $R$, just subsequent asset sales, not the flow of imputed rental income during the period of ownership. Thus, both Blueprints and the Meade Committee viewed the unregistered/nonqualified treatment as necessary for these assets. For other assets, such as closely-held businesses, the ease of shifting factor payments between wages and returns to capital suggested that such assets be subject to cash flow taxation, with no option for owners to leave such assets outside the system.

\section{B. Origin versus Destination Basis}

One particular element of cash flows about which there has been considerable debate is those from net foreign assets, $\left(R^{f}-I^{f}\right)$. Under a standard destination-based value added tax, 
these would be included indirectly, through the border tax adjustments on imports and exports, since the current and capital accounts balance. But some taxes, notably the Hall-Rabushka flat tax, would be imposed on an origin basis and hence would provide no special treatment for the cash flows associated with cross-border investments. From the analogy with other types of asset cash flows, it should be evident that the distinction between these two tax bases lies in the treatment of rents and the normal returns to existing assets. There should be no impact on the incentives for inbound or outbound investment, just on asset values and the present value of government revenues. ${ }^{5}$ Because there should be no impact on cross-border investments, there is no reason why trade flows should be affected, either; with an immediate adjustment of exchange rates, this irrelevance should be what we observe. That is, assuming no differences between the two tax systems in terms of domestic or foreign price levels, a switch from an origin-based VAT to a destination-based VAT should lead to a currency appreciation for the adopting country that should just offset the incipient advantage of exporters and disadvantage of importers under the destination-based system. $^{6}$

To see why the exchange rate would change in this manner, consider the hypothetical experiment in which the exchange rate rose by less than the predicted amount, or not at all. The reduced relative price of domestic goods and services would lead to an improvement of the trade balance that, by expression (3), would have to be offset by a reduction in the capital account balance. But, assuming no change in the future expected path of currency appreciation or deprecation, there would be no wish on the part of international investors to shift from their

\footnotetext{
${ }^{5}$ See Auerbach (1997) for further discussion.

${ }^{6}$ Note that this reasoning does not require perfect competition on the part of domestic firms. As an exchange rate appreciation is equivalent to an ad valorem tax on exports from the point of view of domestic producers, a border adjustment combined with an offsetting exchange rate appreciation leaves marginal revenue conditions unaffected. The same argument holds on the input side with respect to the combined impact of a tax on imports combined with exchange rate appreciation. Thus, regardless of whether firms are price-takers or not, there should be no change in their behavior.
} 
previous investment choices. Thus, there would be an imbalance in the international accounts leading to a further adjustment in the exchange rate until the potential change in trade flows disappeared.

The simplicity of this analysis has done little to offset the skepticism of policy makers and trade "experts." Many skeptics simply refuse to acknowledge the predictions of economic theory or the validity of the national income identity. Others confuse the effects of adopting a consumption tax with the effects of border adjustments per se. From (2'), we can see that any tax policy that reduces consumption, as a shift to consumption taxation might, will increase the trade balance, holding constant income and domestic investment. Yet others confuse the impact of uniform border adjustments with the impact of industry-specific border adjustments. If border adjustments only apply in a particular industry, for example, the exchange rate cannot fully adjust in response, because this would reduce net export demand in other industries and hence overall. Thus, there would be only a partial exchange rate adjustment and a shift in net exports to the industries covered by the border adjustments. And some may think that border adjustments would have the same impact as tariffs, which incorporate one part of the border adjustment (the import tax) but not the other (the export subsidy).

Some skeptics also rely on more sophisticated (but not more compelling) arguments to promote the importance of border adjustments. One argument, for example, is that the analysis given above doesn't apply in a world where countries peg their exchange rates to the dollar, for then dollar appreciation under a destination-based VAT would be held in check by the reserve transactions of foreign governments and central banks. While such transactions would, indeed, lead to a violation of the assumptions needed for the equivalence of the two tax systems to hold, proponents of this argument do not explain why a foreign government would choose to ignore 
changes in the real exchange rate when setting its currency peg. For example, suppose a foreign government seeks to enforce an exchange rate of $e$ units of its currency per dollar under an origin-based tax at rate $t$. Then, the United States shifts to a destination-basis for its tax, the border adjustments increasing the relative price of foreign goods by a factor of $(1+t)$ if the exchange rate is unchanged. If the foreign government wishes to maintain its competitive position, it will seek to devalue its currency by a factor of $(1+t)$ to $e(1+t)$, which should be easy to accomplish because this should be the result if the previous level of reserve operations is maintained. Put another way, if the government's opportunity set has not changed, then why should its choice from this set?

The equivalence of destination-based and origin-based taxes is not exact because of the different treatment of net cash flows under the two systems. As discussed, a destination-based tax would expand the tax base by the present value of rents and normal returns to existing capital associated with a country's net foreign asset position. For the United States today, the net foreign asset position is negative, so the destination-based tax would tend to reduce revenues in present value, to the extent that rates of return on U.S. and foreign assets are equal. ${ }^{7,8}$ To the extent that a country's net asset position is close to zero, this would make little difference in terms of tax revenues. But there could still be a big difference in terms of the impact on asset values, even with a zero net international investment position, because the valuation effects would apply to gross asset positions. The cash flows of all U.S.-owned assets held abroad would

\footnotetext{
${ }^{7}$ Net income from abroad, $R^{f}$, remained positive through 2005 for the United States, even though the U.S. net international investment position has been negative for several years. This indicates that U.S. assets abroad have been earning a higher rate of return than foreign assets in the United States. However, with the increasingly negative U.S. international investment position, net income from abroad still is trending downward, virtually hitting zero in 2005 and falling below zero in the final quarter of that year.

${ }^{8}$ Ironically, another current argument favoring the U.S. adoption of a destination-based VAT is that, given large current U.S. trade deficits, it would raise more money than an origin-based version. This highlights the distinction between short-run and long-run revenue consequences.
} 
be hit by the cash flow tax included in the destination-based VAT, and those of foreign-owned assets held in the U.S. would be subsidized. The fact that the taxes would be collected on traded commodities rather than on the capital flows themselves is irrelevant, because the exchange rate adjustment would shift the incidence of the taxes onto the asset holders. ${ }^{9}$

As an example of the size of the potential asset revaluations associated with border adjustments, consider the case of the United States at the end of 2004, when, according to the Bureau of Economic Analysis, foreign-owned assets in the United States totaled \$11.5 trillion and U.S.-owned assets abroad were $\$ 9.1$ trillion. ${ }^{10}$ The border adjustment of a domestic VAT at a rate, say, of 30 percent, would require a 30 percent depreciation of foreign currencies relative to the dollar - a $\$ 2.7$ trillion loss for U.S. holders of foreign assets, and a gain of $\$ 4.9(\$ 11.5 / 0.7$ $\$ 11.5$ ) trillion for foreign asset holders, relative to a 30 percent VAT with no border adjustment.

\section{The Treatment of Financial Assets and Liabilities}

Following expression (4) above, a tax on consumption requires that gross private income be taxed and that gross investment purchases be deductible or in some other manner effectively excluded from the tax base. Except to the extent that they represent holding of foreign assets, financial positions do not show up in expression (4) because they net out. That is, we could also write expression (4) as:

$$
C=W+(R-I)+\left(R^{f}-I^{f}\right)+(F-J)
$$

\footnotetext{
${ }^{9}$ Indeed, the incidence of these taxes and subsidies does not require full adjustment of the nominal exchange rate; for example, if the domestic price level rose to offset the border adjustment in reaction to the shift from origin to destination basis, no change in the exchange rate would be necessary to maintain equilibrium, but domestic assets would rise in nominal value and hence still appreciate in units of the foreign currency, and U.S.-held foreign assets would have their real values reduced when deflated by the U.S. price level.

${ }^{10}$ http://www.bea.gov/bea/newsrelarchive/2005/intinv04_fax.pdf.
} 
where $F$ is net flows from financial assets and $J$ is net purchases of financial assets, and these would both equal zero if we were considering the economy as a whole.

Note that, as in the case of net foreign assets, the fact that $F$ and $J$ are each zero in the aggregate does not imply the absence of wealth effects from a decision to tax the component flows, simply that these wealth effects cancel. Imposing a cash flow tax on all financial assets and liabilities places a tax on the returns to all existing financial assets and presents a subsidy of equal magnitude to those with financial liabilities. Indeed, this effect would occur even if $F$ and $J$ were not included explicitly in the tax base, if the price level rose and the financial assets and liabilities were not indexed to the price level. Some have argued that the adoption of a VAT would raise the price level by the extent of the tax; such a price increase would simulate the imposition of a cash flow tax on net financial assets (and indeed on all positions not indexed to the price level). It follows, of course, that including financial flows in the tax base and having the price level rise by the extent of the tax would effectively impose the cash flow tax on net asset positions twice.

Leaving aside these distributional effects of including financial flows in the cash flow tax base, these flows would not equal zero if we considered only the flows of the private sector, for then the net cash flows between the private sector and the government would be included in the tax base. This would have the effect of adding the present value of flows from existing government debt to the tax base; once again, nominal assets would be hit twice if the price level rose, in this case raising the present value of tax collections twice because the tax applies to a positive net asset position.

Another variation in the taxation of financial flows would be to impose a cash flow tax on flows of the business sector. Flows within the business sector would, again, cancel out in terms 
of revenue, assuming all businesses are subject to the same tax rate, but flows between the business sector and the household sector would not cancel out. As the business sector is a net debtor to the household sector, this would have the effect of reducing the cash flow tax base by the present value of interest on net existing liabilities, assuming no special transition provisions. Such a variant of the cash flow tax was described by the Meade Committee and an " $R+F$ " base cash flow tax.

An administrative advantage of the $R+F$ base is that it makes it easier to tax the income generated by the financial services sector. Recall that the objective of the consumption tax is to include all capital income components of GNP, $R$, in the tax base. But some components of capital income may be disguised as interest payments. Including all elements of $R+F$ in the tax base obviates the need to identify components of $F$ that should really be included in $R$. Thus, an $R+F$ base VAT applied to a financial services company would automatically tax interest-rate spreads that compensate the company for the services it renders, and would eliminate the incentives of an integrated company offering both real and financial services to shift profits from real to financial activities.

Unfortunately, as it eliminates one complicating distinction, the $R+F$ base introduces another. As the Meade Committee Report (Chapter 12) observed, the transactions of the business sector are related by an identity which, using our notation, may be written

$$
(R-I)+(F-J)+S=0
$$

where $S$ equals net transactions in corporate shares and dividend payments, i.e., the net flows between firms and their shareholders. Under an $R$ base tax that ignores financial transactions between the business and household sectors, both $(F-J)$ and $S$ are omitted from the tax base. 
Thus, transactions between a firm's creditors and shareholders are treated identically. Just as new share issues and dividends are excluded from the tax base, so are borrowing and interest payments. But, once $(F-J)$ is included in the tax base, transactions with creditors are subject to a cash-flow tax - with taxes on borrowing and deductions for interest expenses and repayment of principal - while transactions with shareholders are still ignored.

How serious a problem this distinction in how the sources of funds are treated under the $R+F$ base depends on the extent to which firms can manipulate payments between debt and equity, for example by issuing debt and equity to the same party and overstating deductible interest payments while understating nondeductible dividends. The problem is similar to that under the $R$ base of shifts on the output side between the firm's real and financial activities, so the decision of whether to group financial flows with the firm's transactions with its customers or with the firm's transactions with its shareholders depends in part on where the problem of manipulation is greater.

There is also an analogy here to the problems attendant upon a decision to allow a choice under an individual expenditure tax between registered/qualified assets and unregistered/unqualified assets, to the extent that flows associated with individual assets can be manipulated $^{11}$

\section{The Timing of Tax Payments}

Aside from the differences in their treatment of rents and normal returns to existing assets, the cash-flow and tax-exempt approaches also differ with respect to the timing of tax collections. While tax-exempt treatment simply imposes no taxes, cash-flow treatment arrives at

\footnotetext{
${ }^{11}$ See, e.g., Graetz (1979).
} 
the same zero present value through deductions and taxes that offset. This distinction has two potentially important effects.

First, with truncated windows for revenue calculations, the tax-exempt approach appears less costly. The result can be distorted policy decisions, an example of which is the trend away from traditional IRAs (which provide cash flow treatment to contributed funds) to Roth IRAs (which provide tax exempt treatment) in recent years in the United States, including the use as a revenue "source" provisions encouraging investors to switch from the former to the latter. Another example, already cited above, is viewing border adjustments as a source of revenue when, in present value, they likely would involve a net revenue loss.

Second, with tax rates that vary over time, the cash-flow tax no longer imposes a zero effective tax rate on capital accumulation. Indeed, the effective tax rates could be very positive or negative if large tax rate changes occur over short periods, given that gross investment is fully deductible in one year and gross returns are fully subject to taxation in others. This led Bradford (1998) among others to suggest replacing the immediate deduction of investment with a procedure of carrying the basis of investment forward with interest and taking depreciation deductions in accordance with the timing of economic depreciation. While the deductions would have the same present value as expensing with tax rates constant, their timing would eliminate the distortion of investment decisions: marginal investments would face a zero effective tax rate, as only supernormal rents would be subject to taxation in any period.

This "basis with interest" approach thus combines the insulation from tax rate changes and the timing of revenues of the tax exemption approach with the taxation of rents present under the cash flow tax. However, this compromise has a major drawback relative to the simple cash 
flow tax (and, obviously, relative to tax exemption) of requiring that investors keep track of asset bases and calculate depreciation allowances over time.

Not having to measure capital income has generally been viewed as one of the major simplifications of cash flow taxation. Indeed, rather than attempting to make a cash flow tax look more like an income tax, Auerbach and Bradford (2004) adopted the opposite approach of considering how to make an income tax look more like a cash flow tax. They developed a method of using the cash flow tax with rising tax rates over time to simulate an income tax, suggesting that the advantages of eliminating basis could outweigh the disadvantage of susceptibility to time-varying tax rates, particularly with financial innovation making the identification of specific assets more difficult.

\section{E. Individual versus Business Taxation}

Consumption taxes can be imposed either at the business level or at the individual level. The working of the business-level VAT has already been discussed. A cash flow personal expenditure tax, sometimes called a consumed income tax, would start with the individual income base and subtract net saving. Assuming that saving is measured consistently with income, all income that is not saved is consumed, so the result would be a consumption tax. Similarly, one can adopt a mixed approach, as under the flat tax or the $\mathrm{X}$ tax, that starts with a VAT and shifts the taxation of wages from the business to the individual level. While these approaches are all equivalent at the abstract level, they would likely differ in practice.

First, the business-household borderline is not clear, and some income producing activities might be included in the household sector under a business level consumption tax. For example, how would a household's speculative holding of land be treated? 
Second, progressive taxation based on an individual's circumstances can, realistically, only be applied to taxes at the individual level. Hence, the flat tax and the $\mathrm{X}$ tax transfer the wage component of the tax base to households in order to apply progressive rate schedules to that base.

Third, the difference in statutory incidence would also affect the measured price level. A value-added tax, or a retail sales tax, added to factor incomes, would have a higher measured price level than if the same tax were collected from individual consumers through a consumed income tax. Although this difference simply reflects a convention in how the price level is measured - including indirect taxes but excluding direct taxes - it would have real effects to the extent that the price level matters, as for example for the indexation of transfer payments. It would also matter to the extent that wages were sticky, either through explicit rigidities due to contract and minimum wage provisions, or due to other sources of sluggish adjustment.

Fourth, market prices of assets will differ according to the level at which taxes are collected. In comparing the impact on market values of a VAT and a consumed income tax, it is helpful to consider the treatment of traditional IRAs under current law. The securities inside an IRA have one market value, but this is not the after-tax value of the IRA to its owner, i.e., what the holder of the IRA could sell the account for if the future tax liability due on withdrawals was transferred along with the asset. If all investments were through IRAs, as effectively would be the case under an individual level consumption tax, the after-tax value of the existing IRA to the investor would fully capitalize these deferred taxes, because a new IRA composed of the same portfolio of securities would face no taxes in present value under a system with constant tax rates over time. ${ }^{12}$ If the taxes were payable not by individuals holding the IRAs, but instead by the

\footnotetext{
${ }^{12}$ The story is more complicated under the current system in which IRAs provide a higher rate of return than fully taxed assets. If the alternative investment is subject to income taxes but not subject to taxes on withdrawal, then
} 
firms issuing the securities held in the IRAs, then the market values of the securities would already reflect the deferred taxes. There would be no difference in the after-tax value of the securities to investors, but the market values would adjust to offset the shift in statutory incidence of the tax from investors to firms. ${ }^{13}$

Because market values under economically equivalent consumption taxes can vary significantly, the impact on market values of adopting a consumption tax depends very much on how the tax is imposed, even if the ultimate economic impact of the tax does not. Consider a shift from the current U.S. tax system to a consumption tax. As discussed above, a consumption tax without transition relief incorporates a form of capital levy in its tax on rents and the normal returns to existing assets. This capital levy, in itself, would cause the after-tax values of assets to fall. An offsetting effect on asset values comes from an increase in asset demand due to a shift to the more favorable treatment of new investment. Still, it is likely that the after-tax values of existing assets to investors would fall. ${ }^{14}$ But the market values of the assets could rise if some taxes were shifted from the business level to the individual level. Given that the depreciation provisions of the current U.S. corporate income tax favor new assets over existing assets, the values of corporate shares should capitalize this difference, simulating the impact of partial cash

there are offsetting effects on the value of the IRA, the relative impact of deferred taxes declining with respect to the length of the holding period as the advantage of tax-free investment grows. See Poterba (2004) for further discussion.

${ }^{13}$ The same distinction will apply to the domestic prices of foreign assets. Recall that, under a VAT, border adjustments will cause the home currency to appreciate against foreign currencies in proportion to the border adjustment. As border adjustments effectively apply cash flow taxation to net foreign investment, this reduction in the domestic value of existing foreign assets is analogous to the reduction in value of domestic assets under a VAT. Under a consumed income tax, extending cash flow treatment to the purchases and sales of foreign assets would impose the same tax treatment as would border adjustments under a VAT, but would not induce a change in the exchange rate. Investors would be in the same after-tax positions under both systems, but the taxes would be collected at the company level and hence capitalized under the border-adjusted VAT.

${ }^{14}$ See the simulations in Auerbach (1996) or Altig et al. (2001). 
flow taxation ${ }^{15}$. Going to full cash flow taxation, but shifting the entire tax to the individual level, for example by replacing the current corporate and personal income taxes with a consumed income tax, would lower the after-tax values of these assets to investors, but raise their market values, because the taxes on asset sales would be due after the assets were sold.

Finally, some have argued that indirect consumption taxes are a more effective method of collecting taxes from individuals who do not report income or pay tax under the income tax. The logic is that these individuals currently pay no tax, but would be hit by sales tax or VAT on their purchases. Presumably, this supposed benefit of indirect consumption taxes would not apply to a household level consumed income tax, for the tax evader would be no more likely to file a tax return than before. But the underlying logic itself is flawed, as the following discussion illustrates.

\section{F. Activities outside the Tax System}

In a simple world without intermediate inputs or investment, where income equals consumption, it is easy to see the flaw in the previous logic. Imagine that there are two sectors, sector 1 that is covered by the tax system and sector 2 that is not covered. Under the income tax, sector 1 pays taxes while sector 2 does not. Under an indirect consumption tax, sector 1 again pays taxes, while sector 2 does not. Thus, there has been no change in the tax base, and hence no possible reason for any change in tax incidence.

A somewhat more sophisticated analysis that takes intermediate inputs into account doesn't change the basic story. Suppose now that the first sector produces both investment goods and consumption goods; that the investment goods serve as capital in both sectors; and that both sectors are competitive, so that price equals marginal cost. Then, under an income tax,

\footnotetext{
${ }^{15}$ See, e.g., Auerbach (1983).
} 
the costs of production and hence prices in the covered and uncovered sectors will be, respectively:

$$
p_{1}=\frac{w}{1-t} l_{1}+p_{1} \frac{r}{1-t} k_{1} \quad ; \quad \text { (6.2) } \quad p_{2}=w l_{2}+p_{1} r k_{2}
$$

where $w$ and $r$ are the required after-tax returns to labor and capital, $t$ is the income tax rate, and $l_{i}$ and $k_{i}$ and unit labor and capital requirements in each sector. Under an indirect consumption tax at rate $\tau$, the effective tax rate on capital income becomes zero in the covered sector, so these expressions become:

$$
p_{1}=\frac{w}{1-\tau} l_{1}+p_{1} r k_{1} \quad ; \quad \text { (7.2) } \quad p_{2}=w l_{2}+p_{1} r k_{2}
$$

Assuming that the tax change is revenue-neutral in present value, $\tau$ must be enough higher than $t$ to make up for the revenue lost by setting the effective tax rate on capital to zero. Since only sector 1 is subject to taxation, this equal-revenue requirement implies that, for given values of $w$ and $r$, the solution for $p_{1}$ in expressions (6.1) and (7.1) must be the same; hence, so are the solutions for $p_{2}$ in (6.2) and (7.2). Thus, with no change in $w$ and $r$, there will be no change in the relative production costs or prices of the commodities produced by the covered and uncovered sectors. However, the reduction in the cost of capital relative to labor in sector 1 will encourage a shift from labor to capital in production, and this increased demand for capital relative to labor will raise $r$ relative to $w$. As discussed further in Hines (2004), this change will raise relative costs in whichever sector is more capital intensive, quite plausibly the covered sector. Thus, the shift to an indirect consumption tax like a VAT may actually encourage the expansion of activity in the uncovered sector. 


\section{G. Hybrid Tax Systems}

It is frequently asserted that tax systems that have some of the characteristics of an income tax and some of the characteristics of a consumption tax have effects on behavior that lie between those of an income tax and those of a consumption tax. For example, the 2006 Economic Report of the President says: "the personal income tax is actually a hybrid incomeconsumption tax, so that some of the taxes collected through the U.S. tax system, and those of other countries, might be thought of as taxes on consumption" (p. 115). The provisions to which the passage refers include tax-sheltered saving such as IRAs and relatively low rates of tax on dividends and capital gains. But having favorable treatment for some types of capital income, while it does reduce taxes on capital income, reduces taxes in a different way than, say, shrinking the income tax and replacing the lost revenue with a consumption tax. First, the differential treatment of assets distorts the allocation of capital. Second, the differential treatment of assets and liabilities and, in particular, the full deductibility of interest combined with reduced taxation of capital income, encourages borrowing to invest in tax favored assets, rather than saving. ${ }^{16}$

\section{The Consumption Tax and Economic Efficiency}

There are several strands of the literature arguing that a consumption tax would be more efficient than an income tax. I will not attempt a detailed survey of this rich literature here, but will simply try to highlight some key results to provide a flavor of where things stand. ${ }^{17}$

\footnotetext{
${ }^{16}$ One might argue that the borrowed funds still must come from somewhere and therefore require additional saving, but even this is not necessarily true because the funds can come from one's own sheltered investments. For example, an individual's pension fund saving can be used to purchase that same individual's new interest-deductible mortgage. In this example, there would be no net saving, as the increased borrowing would exactly equal the increased pension assets.

${ }^{17}$ For a good recent survey of much of this literature, see Zodrow (2005).
} 
One of the most frequently cited papers in this literature is that of Atkinson and Stiglitz (1976), who showed, under the assumption that preferences are weakly separable into consumption and leisure, that a progressive labor income tax is optimal by itself, i.e., that no variation in commodity taxes can improve social welfare. Although weak separability of preferences is not assured, it is a relatively weak restriction and it is not clear in which direction deviations would point in terms of differential commodity taxes. If one interprets the different consumption goods in the Atkinson-Stiglitz analysis as consumption in different periods, then the result may be interpreted as calling exclusively for a progressive tax on labor income or, in their model equivalently (because there are no initial assets and no transfers to other individuals), a progressive tax on lifetime consumption.

Even if the Atkinson-Stiglitz restriction on preferences is not satisfied, this violation does not necessarily imply that one would want to have higher taxes on future consumption than on current consumption, as would be effectively imposed by a capital income tax. A priori, a capital income subsidy is just as likely to be optimal as a capital income tax. Indeed, as the household's horizon lengthens, in the limit to the infinite horizon, the case against any significant tax on capital income is strengthened by another important result in the literature.

Perhaps the most striking result from infinite horizon models is the finding of Judd (1985) and Chamley (1986) that, for a system with taxes on labor and capital income, the longrun tax on capital income should be zero. Thus, leaving aside the distinction already discussed between consumption and wage taxes relating to the treatment of initial assets and rents, the result calls for consumption tax treatment in the long run. This conclusion is quite general in some respects, not depending on individual preferences taking a particular form, for example. The intuition is also very simple. For any given set of individual preferences, we might improve 
efficiency by taxing consumption in different periods at different rates. Taxing future

consumption more heavily than current consumption could be achieved by taxing capital income. But it is implausible that we would want to tax consumption more and more heavily as we move into later and later periods, as would be the case if positive capital income taxes continued to apply. Thus, at some point, regardless of the exact form of preferences, the capital income tax will have to converge to zero.

Although Judd and Chamley derived their results in simple representative agent models without ability differences or progressive taxation, the logic would apply just as well in the Atkinson-Stiglitz framework: even if one didn't want uniform consumption taxation, one wouldn't want to have arbitrarily large distortions facing consumption at distant future dates. Further, the intuition associated with the Judd-Chamley result still resonates for finite horizon models, in that a positive capital income tax in every year would still impose a very high effective tax rate on consumption, say, 50 years in the future.

Aside from the usual restrictions that any modeling assumptions impose, however, there are particular problems in applying the Atkinson-Stiglitz result to the design of taxation over time. First, Atkinson and Stiglitz assume that each household has just one form of labor supply. Leaving aside the issue of how different members of a household should be treated at a given point in time, this assumption also ignores the fact that there is labor income in different periods. Even if consumption were separable from all forms of leisure, there is no presumption that leisure at different dates should be subject to the same tax schedule. One might, for example, think that age-specific labor income tax schedules would make sense. ${ }^{18}$ But, more importantly, applying a static analysis like that in the Atkinson-Stiglitz paper to behavior over time ignores

\footnotetext{
${ }^{18}$ See, e.g., Kremer (2001).
} 
the fact that we observe the labor supply and consumption decisions of early periods before those of later ones. Thus, we might wish to implement a tax system in future periods that is conditioned on current decisions. ${ }^{19}$ Considering such a dynamic model, Golosov et al. (2003) found that the Atkinson-Stiglitz result about uniform commodity taxation still applied across commodities within a given period, but that a positive capital income tax was generally optimal. The intuition is that higher capital income makes it more difficult for the government to impose redistributive labor income taxation, because the cost to high ability individuals of not working hard is reduced by the presence of additional resources. Taxing capital income therefore weakens the self-selection constraints that the government's tax system must satisfy, allowing it more scope for redistribution.

Thus, even though capital income taxes distort consumption more and more over the infinite horizon, zero taxes on capital income may not be desirable if we seek to implement a plan for redistributive taxation. On the other hand, the literature lacks results suggesting that labor income and capital income should be treated equally by the tax system, and there is no obvious intuition suggesting that such a result might make sense, leaving aside practical difficulties that arise in distinguishing capital income and labor income. It is no accident that the literature has focused on whether it is efficient for capital income taxes to be zero, rather than on whether there should be equal taxes on capital income and labor income. Even with all the complications in the literature, then, there is a strong theoretical basis for thinking that consumption taxes will be more efficient than income taxes. But theory typically fails to tell us how great the efficiency difference might be. Given the transition costs of moving from one tax

\footnotetext{
${ }^{19}$ This is distinct from the incentive that a government will have to deviate from a previously announced policy, for example to announce a capital subsidy but then implement a capital income tax once capital has been accumulated.
} 
system to another, it could easily be the case that a small efficiency gain in moving to a consumption tax could be outweighed by the transition costs of doing so.

\section{A. Previous Results from Simulation Models}

Because the magnitude of the potential efficiency gain from adopting a consumption tax is important and yet difficult to discern from theory, there have been substantial efforts to assess the relative efficiency of income and consumption taxes using numerical simulations models with an empirical basis for their parameter assumptions. One model commonly used for this purpose is that of Auerbach and Kotlikoff (1987). In addition to the results published there comparing the transition from an income tax to either a wage tax or a consumption tax, subsequent papers have considered transitions from a more realistic version of the current tax system to a variety of specific tax systems, such as the flat tax or the $\mathrm{X}$ tax, in both the original Auerbach-Kotlikoff model (Auerbach 1996) or an extended version of the model that has individuals varying with respect to ability and lifetime income (Altig et al. 2001).

The findings in Auerbach and Kotlikoff (1987) are that a shift from an income tax to a consumption tax would increase economic efficiency, while a shift to a wage tax would reduce economic efficiency. The key difference between the two results for apparently similar tax systems is the treatment of assets in transition. Both a consumption tax and a wage tax would remove the distortion facing intertemporal consumption decisions, a change for which the literature would lead us to expect an efficiency gain. But a consumption tax would include in the tax base the returns to existing capital (there are no economic rents in the model), which increases the estimated efficiency gain under the model's assumption that this tax is an unanticipated capital levy that can be used to reduce distortionary taxes further. A wage tax, on the other hand, provides no such capital levy. Further, by eliminating capital income taxes that 
those accumulating wealth had expected to pay, adoption of a wage tax in a sense provides a capital bonus, which has the opposite impact on efficiency of a capital levy, working against the efficiency gains from eliminating the intertemporal consumption distortion. Thus, as the simulations confirm, it is possible for a shift to wage taxation to reduce economic efficiency even as it removes the intertemporal distortion of consumption.

These simulation results do not tell us how large the potential efficiency gains are exclusively from eliminating the intertemporal consumption distortions, because they combine this change with a change in the treatment of existing assets. But the fact that the treatment of existing assets can determine whether the overall efficiency gain is positive or negative suggests that the choice of transition provisions is critical. Auerbach (1996) confirms that providing transition relief within a given system, such as the flat tax, can have a significant impact on longrun output and economic efficiency, in some instances making the efficiency gains disappear entirely. Altig et al. (2001) do not estimate efficiency effects but find generally similar results with respect to the effects of transition relief on long-run output. ${ }^{20}$

None of the simulation results just cited incorporates the potential benefits of consumption taxation of taxing capital income more uniformly (at a rate of zero, in this instance). On the one hand, such benefits might be considerable, given the significant variation in effective tax rates on different investments. On the other hand, such benefits may be largely possible under the income tax. Although one of the argued advantages of the consumption tax is

\footnotetext{
${ }^{20}$ As is discussed in the recent report of the President's Advisory Panel on Tax Reform (2005, p. 174), how the transition relief is provided can determine whether the long-run output gain from a consumption tax is reduced. In Auerbach (1996) and Altig et al. (2001), the cost of transition relief was spread smoothly over the indefinite future and thus permanently raised taxes and reduced output. If, instead, the cost of transition relief were paid for entirely during a short transition period, the long-run impact on output and tax rates would be nil - the tax system would be identical to the case without transition relief, and so the economy would look the same as well. But long-run output gains and efficiency gains are distinct, and it is likely that concentrating the cost of transition relief would reduce the efficiency gains from tax reform even more than paying for such relief smoothly over time, because of the nonlinear relationship between deadweight loss and marginal tax rates.
} 
that it is much easier to tax asset income uniformly under that system than under an income tax, many of the very large distortions under the current income tax, such as the distinctions between debt and equity and between owner-occupied housing and other assets, could be substantially reduced without forsaking the income tax.

For example, Hubbard (1997) argues that one should think of the switch from our current tax system to a consumption tax in terms of two steps, the first a move to a clean, broad-based income tax that removes the inter-asset distortions of the current tax system, and the second a move from this reformed income tax to a consumption tax. This decomposition gives credit for removing inter-asset distortions to the initial tax reform step rather than to adopting a consumption tax.

Hubbard further argues that since both the income tax and the consumption tax hit economic rents, and since both tax the returns to risk-taking in the same manner, the only distinction between their treatments of capital income is the income tax on the safe rate of return. As this safe rate of return is not large, the distinction between the income tax and consumption tax does not appear to be large, either.

\section{B. New Simulation Results}

If the safe rate of return is close to zero, then how large can be the gains from reducing the tax rate on this return to zero? In particular, to what extent do the simulation results just discussed, which are obtained from models in which entire rate of return is treated as the normal returns to capital, overstate the efficiency gains from adopting a consumption tax? This is a difficult question to answer, because there is no simple way of extending the models to incorporate aggregate risk, in which the risky and safe rates of return are determined in equilibrium and the risk premium will change as the tax system and equilibrium change. We can 
get some idea of how the results might change, however, by considering a simpler experiment, in which the economy's capital intensity is held constant but the initial rate of return to capital is taken to be substantially lower than in the simulation results discussed earlier.

Table 1 reports summary statistics for simulations using the basic Auerbach-Kotlikoff model. For the base case simulations, all of the preference and production parameters are the same as those used for the base case simulations in Auerbach and Kotlikoff (1987) and Auerbach (1996), except that costs of adjustment are assumed to exist for investment. A 25 percent proportional income tax is assumed, with no other taxes or government debt. For each simulation of a transition to a new tax system, the table presents three summary statistics: the percentage increase in output in the long run, the percentage gain in welfare of the representative individual in the long run (expressed relative to full lifetime resources - the present value of the individual's labor endowment, out of which consumption and leisure are financed), and the percentage gain in economic efficiency, calculated as the long-run gain in welfare when generations born prior to the beginning of the transition are compensated for gains or losses in welfare and all subsequent generations share equally the gains (or losses) from the change in tax policy. $^{21}$

The first row of Table 1 presents the results of a simulation of an immediate shift from the income tax to a proportional consumption tax. The long-run output gain is nearly 8 percent and the long-run gain in welfare is nearly 4 percent. The efficiency gain is considerably smaller, just over 0.5 percent, because a large share of the long-run gains comes from intergenerational redistribution. The second row of the table gives results for a simulation of an immediate switch to a wage tax, showing a drop in long-run output and long-run welfare, and an efficiency loss

\footnotetext{
${ }^{21}$ Further details of the simulation methodology and parameter assumptions may be found in Auerbach and Kotlikoff (1987) or Auerbach (1996).
} 
that is smaller in absolute value than the long-run welfare loss once the capital bonuses of early generations are neutralized. These results are consistent with those simulation results discussed earlier, in particular the efficiency gain under the consumption tax and the efficiency loss under the wage tax.

Consider now the effects of reducing the rate of return. For these alternative simulations, I reduce two parameters, the capital intensity of production and the rate of time preference, so that the capital-output ratio remains constant in the initial steady state while the interest rate in the initial steady state is reduced to 40 percent of its original value, from 7.90 percent to 3.16 percent. $^{22}$

Before discussing the results of this experiment, it is useful to go through the intuition regarding the effects that this change in assumptions should have. For the transition to a wage tax, we should expect all the effects to be smaller in absolute value, for as capital income becomes smaller as a share of total income, the differences between a wage tax and an income tax become less significant; the capital bonus provided to earlier generations is reduced, as is the efficiency gain from removing the intertemporal distortion. Although these effects work in opposite directions, we know that as the rate of return converges to zero, the wage tax and the income become identical and hence the net change in all summary statistics converges to zero. As there is no reason to suspect that one of these effects should phase out more quickly than the other as the initial interest rate goes down, we would expect that a partial reduction in the initial interest rate would also reduce the impact of a transition to a wage tax.

\footnotetext{
${ }^{22}$ In the model's Cobb-Douglas production function, the capital intensity parameter in the production function, $\beta$, equals capital's share of output, $r \kappa$, where $r$ is the before-tax interest rate and $\kappa$ is the capital-output ratio. In the base case, $\beta=0.25$, consistent with capital's observed income share of about one quarter. I reduce $\beta$ to 0.10 and then reduce the pure rate of time preference from its original value of 0.015 so that enough saving is generated to maintain $\kappa$ at its original value in the initial steady state. (The new value of the pure rate of discount is -0.009 .) Since $\kappa$ stays the same, $r$ must drop by the same percentage that $\beta$ does, i.e., from 0.25 to 0.10 , or by 60 percent.
} 
For a consumption tax, the intuition is not quite as clear. Again, as the initial interest rate falls, the efficiency gain from eliminating the intertemporal distortion falls. But, even at a very low interest rate, the consumption tax's capital levy seems, at least at first, to remain fully in place. That is, consumption of existing assets will still be fully taxed under a consumption tax, even if these assets generate a low rate of return. However, the value of the capital levy to the government in terms of reducing distortionary taxes will still be reduced. If one thinks of the capital levy as a government asset providing an infinite stream of future returns that can be used to reduce wage taxes in future years, these returns will be lower, given the size of the capital levy, if the rate of return is lower. Hence, under the consumption tax as well, we should expect smaller efficiency gains for a lower initial interest rate.

The third and fourth rows of Table 1 confirm the intuition of the previous two paragraphs. All measures move substantially closer to zero, particularly the efficiency effects of the two tax policies. But, there may be more to the story.

First, recall that a consumption tax alleviates the tax on the safe return to capital, but not on economic rents. To the extent that the higher observed return to capital in the economy, which the original parameter choices of the Auerbach-Kotlikoff model aimed to match, represents economic rents rather than returns to risk taking, the capital levy of the consumption tax will provide a larger stream over time than those generated by the previous consumption tax simulation. That is, even though the normal rate of return to new investment may be low, the capital levy will capture both the normal returns and the rents from existing capital. If the assumption of perfect competition still holds, then these rents are simply returns to fixed factors and provide an efficient tax base. 
To explore how much larger the efficiency gain could be in the presence of economic rents, I consider the extreme case in which the entire gap between the observed return to capital in the economy and the safe rate of return is attributable to economic rents; that is, the flow from the capital levy is as large as in the base case simulations, but the efficiency gain from eliminating the intertemporal distortion is still smaller because of the lower return to new saving. ${ }^{23}$ The result of this simulation is given in the fifth row of Table 1. As expected, the gains in output and efficiency are now much larger, although still smaller than those under the base case, high-interest-rate simulation. That a gap remains makes sense, because even with the restoration of the capital levy's value, getting rid of the intertemporal distortion is still less important. Recall, too, that this simulation reflects the extreme assumption that the entire return to the existing capital stock is either rent or a normal return to capital. If rent accounts for a smaller share of observed returns, the effects will be muted.

\section{Caveats in the Interpretation of Simulation Evidence}

There are two additional considerations that also point toward higher potential gains from reducing taxing on capital income, relative to the low-interest-rate simulations in Table 1.

First, if economic rents are present, there may be more to take into account than just the capital levy on such rents. One should also reconsider the standard assumption of perfect competition. Rents could be generated in a competitive environment, but they also may be the result of imperfect competition. If firms are restricting production to levels at which price exceeds marginal cost, then to the distortions of taxation we must add the additional non-

\footnotetext{
${ }^{23}$ To simulate this scenario, given that the model itself has no economic rents, I combine a higher consumption tax with a wage subsidy, letting the consumption tax account for 250 percent of required revenue and using the excess revenue for the wage subsidy. Because a consumption tax plus a wage subsidy is simply a capital levy, this policy multiplies the capital levy in the transition to a consumption tax by 2.5. This magnification just offsets the lower rate of return that the capital levy generates because the safe interest rate is 0.4 times its original value.
} 
competitive mark-up. Assuming that capital goods markets are among those in which noncompetitive distortions exist, moreover, means that the departure from perfect competition will not simply distort consumption by raising consumer prices, but will also discourage the use of capital in production by raising capital goods prices.

This additional wedge in the capital goods market has two implications for polices that reduce capital income taxation. First, the efficiency gains will be larger, because the reduction is starting from a more distorted initial point. Second, the optimal capital income tax will be lower, because even a zero capital income tax will leave the non-tax distortion of capital use in place. Starting from an infinite horizon model in which the optimal long-run capital income tax would be zero under perfect competition, Judd (1997) finds that the optimal capital income tax is quite negative in a non-competitive environment calibrated to U.S. evidence. While the qualitative implications of this analysis are clear - the efficiency gains from eliminating capital income taxes are bigger than otherwise estimated - the quantitative implications for the life-cycle simulation results discussed here are not clear without further efforts at simulation modeling that incorporate different types of imperfect competition.

Second, one should remember that capital income taxes are not simply symmetric, proportional taxes on capital income. If they were, then the effective tax rate on capital income would not vary with the division of the observed rate of return into its components of safe return, rent, and excess return to risk-taking - the tax base would be capital income, and all components of the tax base would have the same tax rate applied. But the tax system is much more complicated, and different factors suggest that as we take risk into account and recognize that the safe rate of return is lower than the observed return to capital, our estimated effective tax rate on that safe rate of return will be higher. 
First, asymmetries in the tax system increase the tax burden on risky assets, a point understood since the work of Domar and Musgrave (1944). That is, the tax burden on the excess return is not zero, so for risky assets this must be added to the burden that the capital income tax imposes on the safe rate of return. Second, because depreciation schedules are not based on actual, ex post economic depreciation, the effective tax rate, even under a symmetric tax system, will vary with the safe discount rate and the extent to which depreciation itself is risky. As shown in the appendix, reducing the assumed discount rate and taking risky depreciation into account will both tend to increase our estimate of the effective tax rate on investment.

Thus, the rate of return relevant in calculating the intertemporal distortion may be lower than has been assumed in simulation models, but the tax rate applicable to that lower rate of return is likely to be higher. How much higher is difficult to know, because it depends on an asset's riskiness, the extent to which the firm is able to offset one asset's losses with another asset's gains, and how tax asymmetries interact with adjustments for risk. ${ }^{24}$

\section{A Further Consideration of Taxation and Risk}

Until now, the discussion of risk has maintained the assumption of market efficiency that taxation provides no insurance function because the private market has already efficiently pooled risks and that the remaining aggregate risk has been allocated among individuals in an efficient manner. While this may be a reasonably accurate assumption for securities markets, it is more problematic for some assets, such as small businesses, and for the returns to human capital as well. As has long been well understood, taxation can serve as a means of pooling risks

\footnotetext{
${ }^{24}$ Auerbach (1983) calculates effective tax rates for different assets taking asymmetric taxation into account, and performs separate calculations of the impact of risk adjustment on effective tax rates. But these calculations are done separately and not integrated.
} 
if markets to pool risks are incomplete. Even distortionary taxes might improve welfare by also improving the efficiency of risk pooling and risk bearing.

Taking this market failure into account can change ones conclusions regarding the desirability of certain tax policies. For example, Nishiyama and Smetters (2005) extend the Auerbach-Kotlikoff model to include idiosyncratic risks to labor income and longevity, and find that the transition from a progressive income tax to a proportional consumption tax would induce an efficiency loss by reducing marginal tax rates on labor income and hence the tax system's implicit provision of insurance. Presumably, the same type of analysis would apply to reductions in capital income taxes to the extent that individuals have idiosyncratic capital risks. In this case, the consumption tax would diverge from the wage tax in its treatment of the return to risk-taking, because the assumption that investors can scale up or down their risky asset positions would no longer apply. The consumption tax, like the income tax, would provide insurance of risky capital income, although, as in the Nishiyama-Smetters analysis, any reduction in marginal tax rates would also reduce the tax system's insurance function.

One needs to exercise some care, though, in thinking about the role of the tax system when markets for risk are incomplete. An analysis needs also to consider why market failure has occurred in the first place. As Weisbach (2004) points out, there are different reasons why individuals might hold undiversified positions. One might be adverse selection. For example, a small business whose owner seeks lay off some of its ownership risk might be perceived as a lemon. In this, case, the tax system's mandatory participation would provide a benefit, as the analysis above suggested. On the other hand, some of the lack of diversification might be due to moral hazard. For example, individuals who insure their human capital risk would have little incentive to work if there is no way to separate the effects on observed income of effort and 
stochastic shocks. A tax system that provided such insurance would have the same disincentive effects, making the insurance function unattractive.

\section{E. Other Behavioral Issues}

Until now, I have said nothing about inheritances and bequests. There are many potential explanations for bequests, and they differ in how they would affect the previous analysis. A strong altruistic bequest motive, as in Barro (1974), turns the decisions of a life-cycle individual into the infinite horizon calculations of a dynasty, thereby increasing the deadweight loss from capital income taxation. On the other hand, accidental bequests that occur because of incomplete annuity markets do not imply any extension of an individual's planning horizon. As confirmed by simulations presented in Altig et al. (2001), even planned bequests, if they are motivated by the benefits of giving rather than the ultimate consumption of one's heirs, need have little impact on the desirability of consumption taxes. Moreover, as already discussed above, the distortions of future consumption resulting from capital income taxation are already significant within the long-horizon life-cycle context, so the potential lengthening of the horizon beyond one's own lifetime doesn't make the efficiency argument for eliminating capital income taxes that much stronger.

Perhaps a more important behavioral realm is the various departures from unconstrained life-cycle saving behavior. As many recent authors have suggested, observed saving behavior, at least on the part of a significant share of the population, seems at odds with fully informed optimization. The implications for capital income taxes are not clear, however, even if individuals fail to save adequately. Depending on the nature of the departure from the standard rational choice assumptions, one might wish to increase tax incentives to save or, alternatively, to tax capital income (Bernheim and Rangel 2005). On the other hand, the institutional 
arrangements associated with saving, such as the default options of employer-sponsored pension plans, may be quite important, even though such arrangements are of minor consequence in the standard model.

Thus, the efficiency effects of a consumption tax may turn on how the change in taxation influences the nature of institutional arrangements. For example, if a shift from targeted saving incentives to a broad-based favorable treatment of saving reduces the appeal of coordinated saving through employer-sponsored plans, saving might actually fall. This effect is by no means certain, for tax reforms could be structured to maintain some advantages for coordinated saving. But there is increasing appreciation that this developing line of research may be of central importance in thinking about tax reform.

\section{The Progressivity of Consumption Taxes}

One of the common concerns about shifting from an income tax to a consumption tax is that a consumption tax would be less progressive than the income tax. There is little of a general nature that can be said about this without reference to the consumption tax under consideration. There is little doubt that a national retail sales tax would shift burdens away from groups with high earnings, or that an $\mathrm{X}$ tax, with progressive rates on labor income, would be less likely to do so. Indeed, the simulations in Altig et al. (2001) find that, in the long run, the distributional effects of a switch from the income tax to the $\mathrm{X}$ tax would be quite neutral, with very similar percentage increases in lifetime welfare for all lifetime-income classes, with the slight differences among the groups favoring those with lower lifetime income. ${ }^{25}$ Rather than comment

\footnotetext{
${ }^{25}$ It is of course conceivable that the percentage welfare gains under the $\mathrm{X}$ tax would have been higher for the very highest lifetime income groups, had Altig et al. (2001) broken down the top 2 percent of he population, their highest group, into still smaller groups.
} 
on the progressivity of the consumption tax per se, it is more useful to touch on a few issues regarding how this progressivity should be judged.

First, the conclusions of Altig et al. (2001) are based on lifetime tax burdens, not the taxes paid in a single year. It is a simple implication of consumption smoothing that consumption will fluctuate less than income, so that the consumption tax base will appear less progressive when evaluated on an annual basis than on a lifetime basis. But it is not clear why one would wish to evaluate progressivity on an annual basis.

Second, in the presence of bequests, the form of consumption taxation and the nature of the bequest motive matter for incidence calculations. The model of Altig et al. (2001) included a realistic level and pattern of bequests, modeled as resulting from a "utility of bequests" motive, but also found that the long-run welfare consequences, including the roughly equal percentage welfare gains by lifetime income groups, were not significantly affected by whether the bequest motive was present. This finding may seem surprising, given that bequests are concentrated among the highest lifetime income groups. One might think, for example, that with bequests not being taxed as consumption, the most affluent would fare much better once bequests were taken into account. Indeed, it has been a concern among many that it would be hard to replicate even lifetime progressivity under a consumption tax, given how large a share of their lifetime resources the rich do not consume. Altig et al. (2001) likely do not encounter this problem because the cash flow component of the $\mathrm{X}$ tax is collected at the business level. As discussed above, this means that the tax is capitalized into the value of assets. ${ }^{26}$ Thus, it hits not just lifetime consumption, but also bequests.

\footnotetext{
${ }^{26}$ Altig et al. (2001, Table 4) find that the long-run value of Tobin's $q$, the ratio of market value to capital, is reduced by 12 percent by the $\mathrm{X}$ tax.
} 
Under a personal consumption tax like the consumed income tax, the same treatment of bequests would require taxing bequests as consumption instead of taxing them upon eventual consumption by heirs. But this shift in the timing of taxation would have no impact on heirs' consumption and hence no impact on the lifetime welfare of donors unless the utility of bequests was based on gross bequests, rather than on the level of consumption that bequests could finance.

Third, long-run calculations do not take into account the incidence of transition provisions. If a consumption tax is implemented without transition relief, for example, the effects of the capital levy on initial generations could be quite progressive. This would be even more the case to the extent that the assets are inherited, given the concentration of bequests and inheritances.

Fourth, it is difficult to analyze consistently the distributional effects of different consumption tax proposals using an annual frame of reference because, as discussed above, the timing of tax payments differs among approaches. For example, a consumption tax with transition relief may impose the same burdens on all individuals as a wage tax, but consumption tax payments will be aligned with consumption, not wages. This difference will wash out of calculations done on a lifetime basis, but will be misleading on an annual basis, regardless of whether individuals are grouped by current income, lifetime income, or some other measure of ability to pay.

Finally, as is always the case in incidence analysis, one needs to distinguish between tax burdens and tax payments. For instance, to the extent that capital income taxes, or consumption taxes, fall on the excess returns to risky assets, the theory discussed above suggests that these taxes impose no burden. Thus, these taxes should be left out when assessing the tax burdens of the respective tax systems. 


\section{Conclusions}

One can draw several conclusions from this paper's analysis. Among them are:

1. There are several attributes that define a consumption tax and distinguish it from an income tax, although not all of these attributes are found in every variant of the consumption tax. Most versions of the consumption tax would impose a zero effective tax rate on the normal returns to capital but a progressive annual consumption tax might not. Most would tax economic rent and the excess return to risk-taking, but a wage tax would not. Most would be imposed on a destination basis, but a flat tax would not. Most would eliminate any consideration of asset basis, but an $\mathrm{X}$ tax in which undepreciated basis is carried forward with interest would not.

2. Some of the key advantages seen by some in adopting some form of consumption tax don't stand simple scrutiny, notably its purported ability to improve the trade balance through border adjustments and to reach economic activities that escape the income tax.

3. Evaluations of consumption taxes need to control for differences in their application, for example with respect to the timing of tax payments, whether or not taxes are structured so as to be capitalized into observed market values of assets, and whether excess returns to risktaking are included in the tax base. These differences are especially a problem when one attempts to evaluate the distributional impact of a tax system using annual tax payments as a measure.

4. The efficiency gains from adopting a consumption tax depend on how the tax is implemented, particularly on how assets are treated during transition. Simulation evidence to date has not taken into account a variety of issues that could significantly affect the estimated efficiency gains from adopting a consumption tax. Some of these issue point toward smaller 
potential gains, while others point toward larger gains. Recent contributions in behavioral economics suggest that a variety of institutional characteristics beyond the effective tax rate on capital income may be very important in determining the effects of adopting a consumption tax. 


\section{References}

Altig, David, Alan J. Auerbach, Laurence J. Kotlikoff, Kent A. Smetters, and Jan Walliser. 2001. "Simulating Fundamental Tax Reform in the United States," American Economic Review 91(3), June, pp. 574-595.

Andrews, William D. 1974. “A Consumption-Type or Cash Flow Personal Income Tax.” Harvard Law Review 87(6), April, pp. 1113-1188.

Atkinson, Anthony B., and Joseph E. Stiglitz. 1976. "The Design of Tax Structure: Direct versus Indirect Taxation.” Journal of Public Economics 6(1-2), July-August, pp. 55-75.

Auerbach, Alan J. 1983. "Corporate Taxation in the United States.” Brookings Papers on Economic Activity 14(2), pp. 1451-1505.

Auerbach, Alan J. 1996. "Tax Reform, Capital Allocation, Efficiency and Growth," in Henry Aaron and William Gale, Editors, Economic Effects of Fundamental Tax Reform. Washington: Brookings, pp. 29-81.

Auerbach, Alan J. 1997. "The Future of Fundamental Tax Reform." American Economic Review 87(2), May 1997, pp. 143-146.

Auerbach, Alan J., and David F. Bradford. 2004. "Generalized Cash-Flow Taxation.” Journal of Public Economics 88(5), April, pp. 957-980.

Auerbach, Alan J., and Laurence J. Kotlikoff. 1987. Dynamic Fiscal Policy. Cambridge: Cambridge University Press.

Barro, Robert J. 1974. “Are Government Bonds Net Wealth?” Journal of Political Economy 82(6), November, pp. 1095-1117.

Bernheim, B. Douglas, and Antonio Rangel. 2005. "Behavioral Public Economics: Welfare and Policy Analysis with Non-Standard Decision Makers.” NBER Working Paper 11518, July.

Bradford, David F. 1986. Untangling the Income Tax. Cambridge: Harvard University Press.

Bradford, David F. 1998. "Transition to and Tax Rate Flexibility in a Cash-Flow Type Tax." In James M. Poterba, Editor, Tax Policy and the Economy 12, pp. 151-172.

Bradford, David F., and the U.S. Treasury Tax Policy Staff. 1984. Blueprints for Basic Tax Reform, $2^{\text {nd }}$ Edition. Arlington, VA: Tax Analysts

Bulow Jeremy I., and Lawrence H. Summers. 1984. "The Taxation of Risky Assets." Journal of Political Economy 92(1), February, pp. 20-39. 
Chamley, Christophe. 1986. "Optimal Taxation of Capital Income in General Equilibrium with Infinite Lives.” Econometrica 54(3), May, pp. 607-622.

Domar, Evsey D., and Richard A. Musgrave. 1944. "Proportional Income Taxation and RiskTaking." Quarterly Journal of Economics 58(3), May, pp. 388-422.

Fisher, Irving. 1939. “The Double Taxation of Savings.” American Economic Review 29(1), March, pp. 16-33.

Golosov, Mikhail, Narayana Kocherlakota, and Aleh Tsyvinski. 2003. "Optimal Indirect and Capital Taxation.” Review of Economic Studies 70(3), July, pp. 569-587.

Gordon, Roger H. 1985. "Taxation of Corporate Capital Income: Tax Revenues versus Tax Distortions.” Quarterly Journal of Economics 100(1), February, pp. 1-27.

Graetz, Michael J. 1979. "Implementing a Progressive Consumption Tax." Harvard Law Review 92(8), June, pp. 1575-1661.

Hall, Robert, and Alvin Rabushka. 1985. The Flat Tax. Stanford, CA: Hoover Institution Press.

Hines, James R., Jr. “Might Fundamental Tax Reform Increase Criminal Activity?” Economica 71, August, pp. 483-492.

Hubbard, R. Glenn. 1997. "How Different are Income and Consumption Taxes?” American Economic Review 87(2), May, pp. 138-142.

Institute for Fiscal Studies. 1978. The Structure and Reform of Direct Taxation. London: Allen and Unwin.

Judd, Kenneth L. 1985. "Redistributive Taxation in a Simple Perfect Foresight Model." Journal of Public Economics 28(1), October, pp. 59-83.

Judd, Kenneth L. 1997. “The Optimal Tax Rate for Capital Income is Negative.” NBER Working Paper 6004, April.

Kaldor, Nicholas. 1955. An Expenditure Tax. An Expenditure Tax. London: Allen and Unwin.

Kaplow, Louis. 1994. “Taxation and Risk Taking: A General Equilibrium Perspective.” National Tax Journal 47(4), December, pp. 789-798.

Kremer, Michael. 2001. "Should Taxes be Independent of Age?" unpublished manuscript, Harvard University.

Nishiyama, Shinichi, and Kent Smetters. 2005. "Consumption Taxes and Economic Efficiency with Idiosyncratic Wage Shocks.” Journal of Political Economy 113(5), October, pp. 1088-1115. 
Poterba, James M. 2004. "Valuing Assets in Retirement Saving Accounts." National Tax Journal 75(2), June, pp. 489-512.

President's Advisory Panel on Federal Tax Reform. 2005. Simple, Fair, and Pro-Growth. Washington: U.S. Government Printing Office.

U.S. Department of the Treasury. 1977. Blueprints for Basic Tax Reform. Washington: U.S. Government Printing Office.

Warren, Alvin C., Jr., 1996. "How Much Capital Income Taxed Under an Income Tax Would Be Exempt Under a Cash-Flow Tax?" Tax Law Review 52(1), pp. 1-16.

Weisbach, David A. 2004. “The (Non)Taxation of Risk.” Tax Law Review 58(1), pp. 1-57.

Zodrow, George R. 2005. "Should Capital Income Be Subject to Consumption-Based Taxation?" Paper presented at the American Tax Policy Institute Conference on "Taxing Capital Income." September. 


\section{Appendix: Effective Tax Rates and the Safe Rate of Return}

The standard formula for the effective tax rate, based on the user cost of capital (see, e.g., Auerbach 1983) is

$$
\tau=\frac{(r+\delta)(1-u z)-(r+\delta)(1-u)}{(r+\delta)(1-u z)-\delta(1-u)}
$$

where $r$ is the real required return, $\delta$ is the rate of economic depreciation, $u$ is the statutory tax rate, and $z$ is the present value of depreciation allowances.

Suppose $\tau$ has been calculated using the observed after-tax rate of return, and we now wish to change the calculation to take into account the fact that the observed return is risky. As discussed in Auerbach (1983), there are two changes necessary. First, the value of $r$ that appears in (A1) and in the calculation of $z$ must be reduced to the safe rate of return. Second, as uncertain depreciation is effectively equivalent to a faster rate of deprecation (a point first noted by Bulow and Summers 1984), the value of $\delta$ must be increased. If we assume that $\tau$ equals $u$ in the original calculation, meaning that the acceleration of depreciation allowances just offsets the effect of inflation at the original values of $r$ and $\delta$, then it may be shown that $d \tau / d r<0$ and $d \tau / d \delta$ $>0$, so both adjustments (reducing $r$ and increasing $\delta$ ) initially increase the estimated effective tax rate. 
Table 1. The Long-Run and Efficiency Gains from Adopting a Consumption Tax: Simple Model Simulations

\section{Percentage Gain in}

$\underline{\text { Simulation }}^{\mathrm{a}}$

Consumption Tax, Base Case

Wage Tax, Base Case

Consumption Tax, Low Interest Rate

Wage Tax, Low Interest Rate

Consumption Tax, Low Interest Rate, Rent ${ }^{\mathrm{c}}$

\begin{tabular}{|c|c|c|}
\hline Long-Run Output & Long-Run Welfare & $\underline{E f f i c i e n c y}^{b}$ \\
\hline 7.94 & 3.95 & 0.55 \\
\hline-2.63 & -2.78 & -1.35 \\
\hline 2.77 & 0.76 & 0.03 \\
\hline-0.91 & -0.42 & -0.14 \\
\hline 6.42 & 1.53 & 0.15 \\
\hline
\end{tabular}

Notes:

${ }^{a}$ All simulations based on the standard Auerbach-Kotlikoff (1987) closed-economy model, starting with an income tax of 25\%, except where specified, and no other taxes or national debt. For the base case, preference and production parameters follow the original model's base case assumptions, except that adjustment costs in investment are assumed. For "low interest rate" simulations, the production share of capital is reduced from 0.25 to 0.09 , and the rate of time preference are adjusted to hold the initial capital-output ratio fixed while reducing the interest rate to 0.4 times its base case value.

${ }^{\mathrm{b}}$ Gains expressed as a percentage of lifetime resources. Long-Run Welfare Gain is gain of generations after the transition is complete. Efficiency Gain is the gain of all generations born post-reform, when lump-sum taxes and transfers are used to neutralize welfare effects of all pre-reform generations.

${ }^{\mathrm{c}}$ The presence of rent is simulated by increasing the implicit capital levy, combining a higher rate of consumption tax with a wage subsidy. 